\title{
Multilevel Analysis: Factors Associated with Overweight and Obesity in Primary School Children in Surakarta, Central Java
}

\author{
Arum Kusuma Rini'1), Eti Poncorini Pamungkasari'), Bhisma Murti²) \\ 1)Masters Program in Public Health, Universitas Sebelas Maret \\ 2)Faculty of Medicine, Universitas Sebelas Maret
}

\begin{abstract}
Background: Life course studies have shown that early onset obesity is a risk factor for morbidity and mortality later in life. In both sexes, rates of diabetes, coronary heart disease, atherosclerosis, hip fracture, and gout were increased in those who were overweight as adolescents. Contextual factor at higher level such as school may have indirect effect on the incidence of overweight or obesity through eating behavior. However, studies into factors affecting child obesity in Indonesia using multilevel approach are lacking. This study aimed to examine factors associated with overweight and obesity in primary school children in Surakarta, Central Java, using multilevel analysis.

Subjects and Method: A case control study was conducted at 25 primary schools in Surakarta, Central Java, from March to April 2018. A sample of 225 primary school children was selected by fixed disease sampling, consisting of 75 children with overweight or obesity and 150 children with normal weight. The variables of children were placed at the first level of the multilevel model. The potential contextual effect of school was determined at the second level. The dependent variable was overweight or obesity. The independent variables were maternal education, maternal body mass index (BMI), physical activity, family income, and school environment. The data were collected by questionnaire and analyzed by a multilevel logistic regression run on Stata 13 .

Results: Child overweight or obesity was positively associated with maternal BMI $\geq 25(b=0.11$; 95\% CI=0.04 to $0.18 ; \mathrm{p}=0.002)$ and high family income $(\mathrm{b}=0.04 ; 95 \% \mathrm{CI}=0.02$ to $0.06 ; \mathrm{p}<$ 0.001). Child overweight or obesity was negatively associated with high physical activity ( $b=-0.03$; $95 \% \mathrm{CI}=-0.05$ to $-0.01 ; \mathrm{p}=0.009$ ). School environment had a negligible contextual effect on child obesity with ICC $=5.08 \%$.

Conclusion: Child obesity is positively associated with maternal BMI $\geq 25$ and family income, and is negatively associated with physical activity. School environment has a negligible contextual effect on child obesity.
\end{abstract}

Keywords: obesity, primary school children, maternal body mass index, physical activity

\section{Correspondence:}

Arum Kusuma Rini. Masters Program in Public Health, Universitas Sebelas Maret, Jl. Ir. Sutami No. 36 A, Surakarta 57126, Central Java. Email: arumkusumarini@yahoo.com.

Mobile: +6282133044191 .

\begin{tabular}{l}
\hline BACKGROUND \\
\hline The obesity prevalence has become the \\
world's overall differences and pandemic \\
with psychosocial health, lifestyle and eco- \\
nomic conditions (Fu et al., 2003). Obesity \\
in children tends to carry over until they are \\
growing up. Increased mortality and \\
morbidity risk of obesity caused by various \\
diseases such as type II diabetes mellitus,
\end{tabular}

cardiovascular, orthopedic, and breathing. Obesity now ranks fifth as a leading global risk for death. At a global level, $44 \%$ of diabetes, $23 \%$ of ischemic heart disease and up to $41 \%$ of certain types of cancers are caused by overweight or obesity (Koiralaa et al., 2015).

Obesity in 2010 is currently increaseing. Children overweight under the age of 
Journal of Epidemiology and Public Health (2019), 4(1): 1-8

https://doi.org/10.26911/jepublichealth.2019.04.01.01

fiveare estimated more than 42 million who live in developing countries. While in 2011 to 2014, children aged 2 to 19 years who are overweight are stable enough estimated for about $17 \%$ affecting 12.7 million (WHO, 2015).

The result of basic health research (2013) shows that the national proportion of population with consumption behavior of fatty foods, cholesterol and fried foods is > 1 times per day $40.7 \%$. The top five provinces above the national average are Central Java $60.3 \%$, Yogyakarta 50.7\%, West Java 50.7\%, West Java 50.1\%, East Java 49.5\% and Banten $48.8 \%$. Obesity is a global challenge for a healthy population that can affect lifestyle changes including diet, physical activity and behavioral changes (Whitfield et al., 2016).

Children from urban areas make their lifestyles and diets sufficiently more risky to be overweight than children living in deprived rural environments (Maciera et al., 2017). Risks to the family will increase the likelihood caused by genetic and environmental factors. Children feeding is too excessive, so they are more likely to be obese (Burrow et al., 2017). Factors influencing obesity are divided into individual factors (physical activity, parenting diet, mother's BMI, maternal and environmental education (Yanuar et al., 2016), and family adherence also affects the incidence of obesity in children (Liu et al. , 2016).

Based on the problem, the researcher is interested to know the analysis of multilevel factors related to obesity in elementary school children in Surakarta.

\footnotetext{
SUBJECTS AND METHOD

\section{Study Design}

This was an analytic observational study with a case control design. The study was conducted in 25 primary schools in
}

Surakarta, Central Java, from March to April 2018.

\section{Population and Samples}

The source population in this study was elementary school students in Surakarta, Central Java. A sample of 225 children was selected by fixed disease sampling, comprising 75 children with overweight and 150 children of normal weight. The exclusion criteria in this study were underweight.

\section{Study Variables}

The dependent variable was overweight/ obesity. The independent variables were maternal BMI, physical activity, family income at level 1, and school environment at level 2.

\section{Operational Definition of Variables} Overweight was defined as a condition indicating the presence of excess body fat measured by the Body Mass Index in children. Data on body weight was measured by digital weight scales. Data on body height was measured by microtoise.

Maternal education was defined as the highest level of education a person has achieved who can get a chance to get a job and automatically accompanied by a better income.

Maternal BMI was defined as a method used in determining the nutritional status of a person. It was done by calculating body mass index based on body weight and height to know the condition of fat accumulation abnormal or excessive in body.

Physical activity involves the gesture of the body in doing something for the process of energy formation. It was done by performing moderate physical activity that releases dry at least 30 minutes a day.

Family income was defined as the wealth or economic source of incoming goods or the increase or repayment of obligations caused by the production of goods, the provision of services within a 
certain period that can be measured and recognized. The school environment was defined as an environmental factor that can also affect a person to become obese.

\section{Data Analysis}

Univariate analysis was conducted to see the frequency distribution and percentage characteristics of subjects. Bivariate analysis was done to study the relationship between obesity and the independent variables using chi-square test and odds ratio calculation (OR) with confidence level (CI) of $95 \%$. Furthermore multivariate analysis was conducted using multilevel logistic regression.

Table1. The Characteristics of Subjects

\begin{tabular}{|c|c|c|}
\hline Variable & Frequency (n) & Percentage (\%) \\
\hline \multicolumn{3}{|l|}{ Gender } \\
\hline Male & 147 & $65 \cdot 3$ \\
\hline Female & 78 & 34.7 \\
\hline \multicolumn{3}{|l|}{ Children's age } \\
\hline$<10$ years old & 101 & 44.9 \\
\hline$\geq 10$ years old & 124 & 55.1 \\
\hline \multicolumn{3}{|l|}{ Mother's education } \\
\hline Low (<senior high school) & 110 & 48.9 \\
\hline High ( $\geq$ senior high school) & 115 & 51.1 \\
\hline \multicolumn{3}{|l|}{ Family Income } \\
\hline Low (<Rp 1,500,000) & 149 & 66.2 \\
\hline High ( $\geq$ Rp 1,500,000) & 76 & 33.8 \\
\hline \multicolumn{3}{|l|}{ Maternal BMI } \\
\hline Not obese (BMI <25) & 170 & 75.6 \\
\hline Obese (BMI $\geq 25)$ & 55 & 24.4 \\
\hline \multicolumn{3}{|l|}{ Maternal occupation } \\
\hline Working at home & 95 & 42.2 \\
\hline Working outside the house & 130 & 57.8 \\
\hline \multicolumn{3}{|l|}{ Physical Activity } \\
\hline Low & 104 & 46.2 \\
\hline High & 121 & 53.8 \\
\hline
\end{tabular}

Table 1 shows that most subjects of primary school children are men for about 147 children (65.3\%), as well as proportionage of children mostly $\geq 10$ years old is equal to 124 (55.1\%). Most of the high educated mothers are 115 (51.1\%).
Research ethics include informed consent, anonymity, confidentiality and Ethical clearance. The ethical clearance in this study was conducted (No. 378 / III / HREC / 2018 Faculty of Medicine of UNS of Dr. Moewardi hospital, Surakarta).

\section{Study Subjects Characteristics}

The subjects of this study were 225 primary school children. The case group (overweight and obesity) consists of 75 elementary school children and 150 primary school students in the control group (normal). The distribution of frequency characteristics of study subjects is described in table 1 .

\section{Research Ethics}

Characteristics of family income mostly have low income that is equal to 149 (66.2\%). Most mothers are not obese (BMI $<25)$, which is 170 (75.6\%).

The characteristics of work mostly work outside the home which is 130 (57.8\%) and most recently known charac- 
teristics with high physical activity that is 121 (53.8\%).

\section{Bivariate analysis of determinants overweight/obesity among primary school children}

Bivariate analysis was conducted to analyze the association between maternal education, maternal BMI, physical activity, family income, and school environment with overweight/obesity. The result of bivariate analysis can be seen in table 2 .

\section{Multivariate analysis by multilevel logistic regression}

Multivariate analysis described about the effect of more than one independent variables on one dependent variable. The method used was multilevel logistic regression by using STATA 13 program.

Table 2. Bivariate analysis on the determinants of overweight/obesity among primary school children

\begin{tabular}{|c|c|c|c|c|c|c|c|c|c|}
\hline \multirow{3}{*}{ Variable } & \multicolumn{4}{|c|}{ Overweight/Obesity } & \multirow{2}{*}{\multicolumn{2}{|c|}{ Total }} & \multirow{3}{*}{ OR } & \multirow{3}{*}{$95 \%$ CI } & \multirow{3}{*}{$\mathbf{p}$} \\
\hline & \multicolumn{2}{|c|}{ Normal } & \multicolumn{2}{|c|}{ Obesity } & & & & & \\
\hline & $\mathbf{n}$ & $\%$ & $\mathbf{n}$ & $\%$ & $\mathbf{N}$ & $\%$ & & & \\
\hline \multicolumn{10}{|l|}{ Maternal BMI } \\
\hline Not Obese & 129 & 75.9 & 41 & 24.1 & 170 & 100 & \multirow[t]{3}{*}{26.58} & \multirow{3}{*}{$1.1-3.5$} & \multirow{3}{*}{$<0.001$} \\
\hline Obese & 21 & 38.2 & 34 & 24.1 & 55 & 100 & & & \\
\hline Physical Activity & & & & & & & & & \\
\hline Low & 43 & 41.3 & 61 & 58.7 & 104 & 100 & \multirow[t]{2}{*}{0.09} & $0.05-$ & \multirow{3}{*}{$<0.001$} \\
\hline High & 107 & 88.4 & 14 & 11.6 & 121 & 100 & & 0.18 & \\
\hline \multicolumn{9}{|l|}{ Family Income } & \\
\hline $\begin{array}{l}\text { Low } \\
\text { High }\end{array}$ & $\begin{array}{c}122 \\
28\end{array}$ & $\begin{array}{l}81.9 \\
368\end{array}$ & 27 & $\begin{array}{l}18.1 \\
62 .\end{array}$ & $\begin{array}{c}149 \\
76\end{array}$ & 100 & 7.75 & $4.15-$ & $<0.001$ \\
\hline High & 28 & 36.8 & 48 & 63.2 & 76 & 100 & & 14.48 & 0.001 \\
\hline
\end{tabular}

Table 3. The results of multilevel logistic regression on the determinants of overweight/ obesity among primary school student

\begin{tabular}{lcccc}
\multicolumn{1}{c}{ Independent variables } & b & \multicolumn{2}{c}{ 95\% CI } & p \\
\cline { 3 - 4 } & & Lower Limit & $\begin{array}{c}\text { Upper } \\
\text { limit }\end{array}$ & \\
\hline Maternal BMI $\geq 25$ & & & & \\
Physical Activity (high) & 0.11 & 0.04 & 0.18 & 0.002 \\
Family Income & -0.03 & -0.05 & -0.01 & 0.009 \\
Random effect & 0.04 & 0.02 & 0.02 & $<0.001$ \\
School & & & & \\
N Observation= 250 & 0.20 & 0.03 & 1.21 \\
Log likelihood =- 475.02 & & & \\
LR test vs. logistic regression, $\mathrm{p}=0.088$ & & & \\
ICC = 5.08\% & & & \\
\hline
\end{tabular}




\section{DISCUSSIONS \\ 1. The effect of maternal education on overweight/obesity among primary school children.}

The result of this study showed that there was a significant effect of maternal education on obesity among Primary School children. Maternal education was the most important factor associated to overweight with the availability of health services and family income, with a good education, parents would know about healthy diet. Physical activity can provide a healthier child's behavior while low parental education would tend to choose fast foods because they were lazy to move and it lead to malnourished diet (Wang et al., 2013).

The author argued that with high maternal education, the mothers have the ability to feed their children without restriction, compared to low-educated mothers, thus influencing obesity in children. In addition, maternal education was also highly necessary for the physical and mental development or intelligence of the children.

Highly educated parents who lived in urban areas were more likely to have weight changes in their children. And higher education could lead to better knowledge, therefore, parents could give healthy foods for their children (Andrianiet al., 2015).

\section{The effect of maternal BMI on overweight/obesity among primary school children}

The result of this study showed that there was a significant effect of maternal body mass index on obesity among primary school children. According to Supariasa and Hardinsyah (2016), the risk of obesity was probably caused by the influence of genes or environmental factors in the family. Maternal BMI was used to measure the relationship between height and weight of an individual to determine health risks.
Excessive weight was associated with the occurrence of certain diseases, such as heart disease or some cancers. Other conditions caused by obesity including hypertension, osteoarthritis stroke, and dyspemia (Dhanaet al., 2018).

Obesity history in parents was associated to the child's genetic in experiencing obesity. A study by Haines et al. (2007), stated that overweight parents have a positive relationship with child's overweight. Hereditary factor was associated with weight gain, BMI, waist circumference and physical activity. If the parents suffered from overweight, then the chances of the children to have overweight were 40-50\%.

\section{The effect of physical activity on the risk of overweight/obesity among primary school children.}

The result of this study showed that there was a significant effect of physical activity on overweight and obesity. Viewed from low physical activity, $58.7 \%$ of children from 104 children have the risk of obesity. Numerous studies have shown that sedentary behavior such as watching television and playing computer games was associated with an increased prevalence of obesity (Yi et al., 2012). Furthermore, parents reported that they would rather see their children watching television at home than playing outside the house without parental supervision so that the parents could complete their task while taking care of their children. In addition, there was an enhancement in the proportion of children who delivered to school and the low level of active participation in sports and active activities, especially girls (Nevil et al., 2017).

A study by Macieira et al. (2017) stated that some of the children did not perform physical activities in their school, only few of them who participated in highactivity exercise for more than 3 hours a 
week and some did low activity less than 2 hours a week. Continued by a daily walk of 30 minutes or more, the rest was spent by watching television, playing games or computer.

A study by Isacco et al. (2017), stated that primary school children with risk of obesity were 55 children, and 34 (24.1\%) of them have obese maternal body mass index (Gajjaard et al., 2014). After doing physical activity, the children took a break of 30 minutes and eat some snacks, after that, each child checked his/her heart rate.

\section{The effect of family income on the risk of overweight/obesity among primary school children}

The result of this study showed that family income has a great effect on obesity in children seen from high family income or groups with middle and upper socioeconomic status. High family income could ease the family in buying and consuming good and expensive foods. Parents with high incomes have a tendency to provide large allowance, and usually the children often consumed modern food/fast food (Liu et al., 2016).

According to Knapp et al. (2018), an enhancement in income could also affect the selection of the type and amount of food consumed. Increased prosperity in the community followed by increased education could change the traditional lifestyle and diet to a practical and ready-to-eat diet that could lead to unbalanced nutritional quality. Consuming fast food would lead to excessive calorie intake that would cause obesity.

\section{The effect of school environment level on the risk of overweight/ obesity among primary school children}

The result of this study showed that the school environment has an effect on overweight/obesity among children because of unhealthy snacks or fast food snacks provided outside the school area.

The family environment was also related to obesity rates which reported that children from high-income families were more likely to have obesity than children with low-income family. Children with high economics were more susceptible to fast food and high sugar on their diet. They also spent more time to play games and have little time to do physical activity (Lee et al., 2016).

The school environment needs to provide facilities, programs, and policies that support the provision of healthy food as well as the improvement of students' physical activity. For example by providing fresh fruits in school canteen and providing various games which improve the physical activity during break time.

\section{REFERENCE}

Burrows T, Skinner J, Joyner MA, Palmieri J, Vaughan K, Gearhardt AN (2007). Food Addiction in Children: Association withthe Obesity, Parental F ood Addition and Feeding Practices, Eating Behavior, 26: 114-120.

Fu WPC, Lee HC, Ng CJ, Tay YKD, Kau CY, Seow CJ, Siak JK, Hong CY (2003). Screening for Chilhood Obesity: International vs Population-Specific Definitions. Which is More Appropriate? International Journal of Obesity, 27(9): 1121-1126.

Galjaard S, Pasman SA, Ameye L, Timmerman D, Devlieger R. Intima-Media Tickness Measurements in the Fetus and Mother During Pregnancy: A Feasibility Study. Ultrasound in Medicine \& Biology. 1-9.

Gunter KB, Nader PA and John DH. (2015).Physical Activity Levels and Obesity Status of Oregon Rural 
Elementary School Children. Preventive Medicine Reports, 2: 478-482.

Hasdianah (2012). Diabetes Melitus pada Orang Dewasa dan Anak-Anak Dengan Solusi Herbal. Yogyakarta: Nuha Medika.

Isacco L, Roche J, Quinart S, Thivel D, Gillet V, Negre V and Mougin F (2017) Cardiometabolic Risk is Associated with the Severity of Sleep-Disordered Breathing in Children with Obesity. Physiology and Behavior, 10. Centers for Disease Control and Prevention.

Kementerian Kesehatan RI (2015). Profil Kesehatan Indonesia 2015. Jakarta: Pusat Data dan Informasi Kementerian Kesehatan RI 2015.

Knapp MB, Hall MT, Mundorf AR, Partridge KL, Johnson CC (2018). Perceptions of School-Based Kitchen Garden Programs in Low-Income, African American Communities. Health Promotion Practice, 20(10):1.

Koirala M, Khatri RB, Khanal V, Amatya A (2015). Prevalence and Factors Associated with Childhood Overweight /Obesity of Private School Children inNepal. Obesity Research \& Clinical Practice, (9): 220-227.

Lee GY, Choi YJ (2016). Effects of an Obesity Management Mentoring Program Children. Applied Nursing Research, 31: 160-164.

Liu W, Liu W, Rong L, Li B, Pallan M, Cheng K, Adab P (2016). Socioeconomic Determinans of Chilhood Obesity Among Primary School Children in Ghoangzhou, China. BMC Public Health, 16:482.

Macieira LMDM, Saraiva JMT, Santos LDC (2017). Overweight and Obesity and Their Associated Factor among Early Adolescence School Children in Urban and Rural Portugal. BMC Nutrion, 3-17.
Murti B (2013). Desain dan Ukuran Sampel untuk Penelitian Kuantitatif dan Kualitatif di Bidang Kesehatan. Yogyakarta: Gajah Mada University Press.

Murti B (2016b). Prinsif dan Metode Riset Epidemiologi. Cetakan pertama. Program Pascasarjana IKM Universitas Sebelas Maret. Surakarta: Yuma Pustaka.

Navalpotro L, Regidor E, Ortega P, Martinez D, Villanueva R, Astasio P (2012). Area-Based Socioeconomic Environment, Obesity Risk Behaviors, Area Facilities and Childhood Overweight and Obesity. Socio-environment and Childhood Overweight. Preventive Medicin, 55(2): 102-107.

Nevil AM, Duncan MJ, Lahart IM, Sandercock G (2017). Cardiorespiratory Fitness and Activity Explains the Obesity-Deprivation Relationship in Children. Health Promotion International.

Scott A, Ejikeme CS, Clottey EN, Thomas JG (2013). Obesity in Sub-Sahara Africa: Development of an Ecological Theoretical Framework. Health Promotion International, 28(1): 4-16.

Supariasa IDN, Bakri B, Fajar I (2016). Penilaian Status Gizi Edisi 2. Jakarta: EGC.

Undang-Undang Republik Indonesia No. 20 Tahun 2003. Tentang Sistem Pendidikan Nasional.

World Health Organization (2014). Report of the First Meeting of the Ad hoc Working Group on Science and Evidence for Ending Childhood Obesity. Geneva, Switzerland:World Health Organization.

World Health Organization.(2015). Fiscal Policies for Diet and The Prevention of Noncommunicable Disease', WHO Regional Office for Europe,36. 
Journal of Epidemiology and Public Health (2019), 4(1): 1-8

https://doi.org/10.26911/jepublichealth.2019.04.01.01

World Health Organization. (2016).Word Health Statistics 2016 monitoring health for the SDGs. Geneva: word health statistics.

Whitfield M, Bhanbhro S, Green G, Lewis K, Hindle L, Levy C (2016). Development a Framework for Estimating the
Potential Impact of Obesity Intervention in A European City. Health Promotion International, 31(3): 684691.

Yanuar EA (2011). Diet Sehat dan Aman Untuk Anak-Anak. Yogyakarta: Rapha Publishing. 